\title{
Philometroides africanus sp. n. (Nematoda: Philometridae), a new tissue parasite of the African pike Hepsetus odoe (Pisces) in Botswana
}

\author{
František Moravec ${ }^{1}$ and Jo G. Van $\mathbf{A s}^{2}$ \\ ${ }^{1}$ Institute of Parasitology, Academy of Sciences of the Czech Republic, Branišovská 31, 37005 České Budějovice, Czech \\ Republic; \\ ${ }^{2}$ Department of Zoology and Entomology, University of the Free State, P.O. Box 339, Bloemfontein, 9300, South Africa
}

Key words: freshwater fish, Hepsetus, parasitic nematode, Philometroides, Botswana, Africa

\begin{abstract}
A new species of philometrid nematode, Philometroides africanus sp. n., is described from female specimens found encapsulated in gill arches and inner surface of gill covers of the African pike, Hepsetus odoe (Bloch), an endemic freshwater fish in Africa, from the Okavango River and Delta in Botswana. This new nematode is characterised mainly by a markedly small and plump body of gravid females (body length 6-9 mm), a separate anterior oesophageal bulb, a conspicuously small oesophageal gland, presence of four pairs of very small submedian cephalic papillae, and absence of any caudal processes. The prevalence of $P$. africanus in African pike of the Okavango Delta was $29 \%$, with the intensity $1-8$ (mean 3 ) encapsulated nematodes per fish. The genus Margolisianum Blaylock et Overstreet, 1999 is considered a junior synonym of Philometroides Yamaguti, 1935 and, consequently, its type species is transferred to the latter as Philometroides bulbosus (Blaylock et Overstreet, 1999) comb. $n$.
\end{abstract}

The African pike, Hepsetus odoe (Bloch), is an endemic African freshwater fish that belongs to the monospecific family Hepsetidae, Characiformes. It is widely distributed throughout western and central Africa, from Senegal southwards to Botswana, where the Okavango River forms the southernmost limit of its distribution (Merron et al. 1990). In the Okavango River and Delta, $H$. odoe prefers the backwaters and is frequently encountered in the quiet, deep water, of channels and lagoons of large floodplains throughout the system (Merron et al. 1990). Juveniles prey on small invertebrates and fish; whereas, the adults eat mostly fish.

During investigations of the parasite fauna of fishes of the Okavango Delta, J.G. Van As and his research team in 1998 and 1999 found small nodules in the gill arches and inner surface of gill covers of numerous specimens of $H$. odoe to each contain a small, plump nematode. A more detailed examination showed that these female nematodes represented a new species of the philometrid genus Philometroides Yamaguti, 1935, which is described herein.

\section{MATERIALS AND METHODS}

Fish were caught by gill nets in different lagoons in the Okavango Delta. A total of 69 specimens of Hepsetus odoe (body length $250-345 \mathrm{~mm}$ ) were obtained and subsequently examined for parasites, of which 57 fish were collected in June-August 1998 and 12 in June-August 1999. The nematodes were removed from the host tissue and were fixed in $4 \%$ formaldehyde solution in physiological saline; pieces of the host tissue containing the parasites for histological evaluation were fixed in $10 \%$ formalin. For light microscopical examination the nematodes were cleared with glycerine. Drawings were made with the aid of a Zeiss microscope drawing attachment and photomicrographs with an Aristoplan photomicroscope. After examination, the specimens were stored in $70 \%$ ethanol. For histological examination, the material was processed by routine paraffin technique, sectioned at $5 \mu \mathrm{m}$, and stained with Harris' haematoxylin and eosin (H\&E). One specimen used for scanning electron microscopy (SEM) was postfixed in $1 \%$ osmium tetroxide, dehydrated through a graded alcohol series, critical point dried, and sputter-coated with gold; it was examined with a JSM-6300 scanning electron microscope at an accelerating voltage of $15 \mathrm{kV}$. All measurements are in $\mathrm{mm}$ unless otherwise stated.

\section{RESULTS}

Family P hi l o m e trid a e Baylis et Daubney, 1926

Philometroides africanus sp. $\mathrm{n}$.

Figs. 1-3

Gravid female (based on 5 specimens; measurements of holotype in parentheses): Body of fixed specimens yellowish to light brown, sometimes with markedly dark-brown intestine visible in it. Body plump, 5.522-9.112 (9.112) long, its maximum width at region of oesophagus end $0.680-1.523$ (1.523); posterior half of body somewhat narrower, 0.272-0.952 (0.952) wide. Cuticle of two largest specimens (body length 

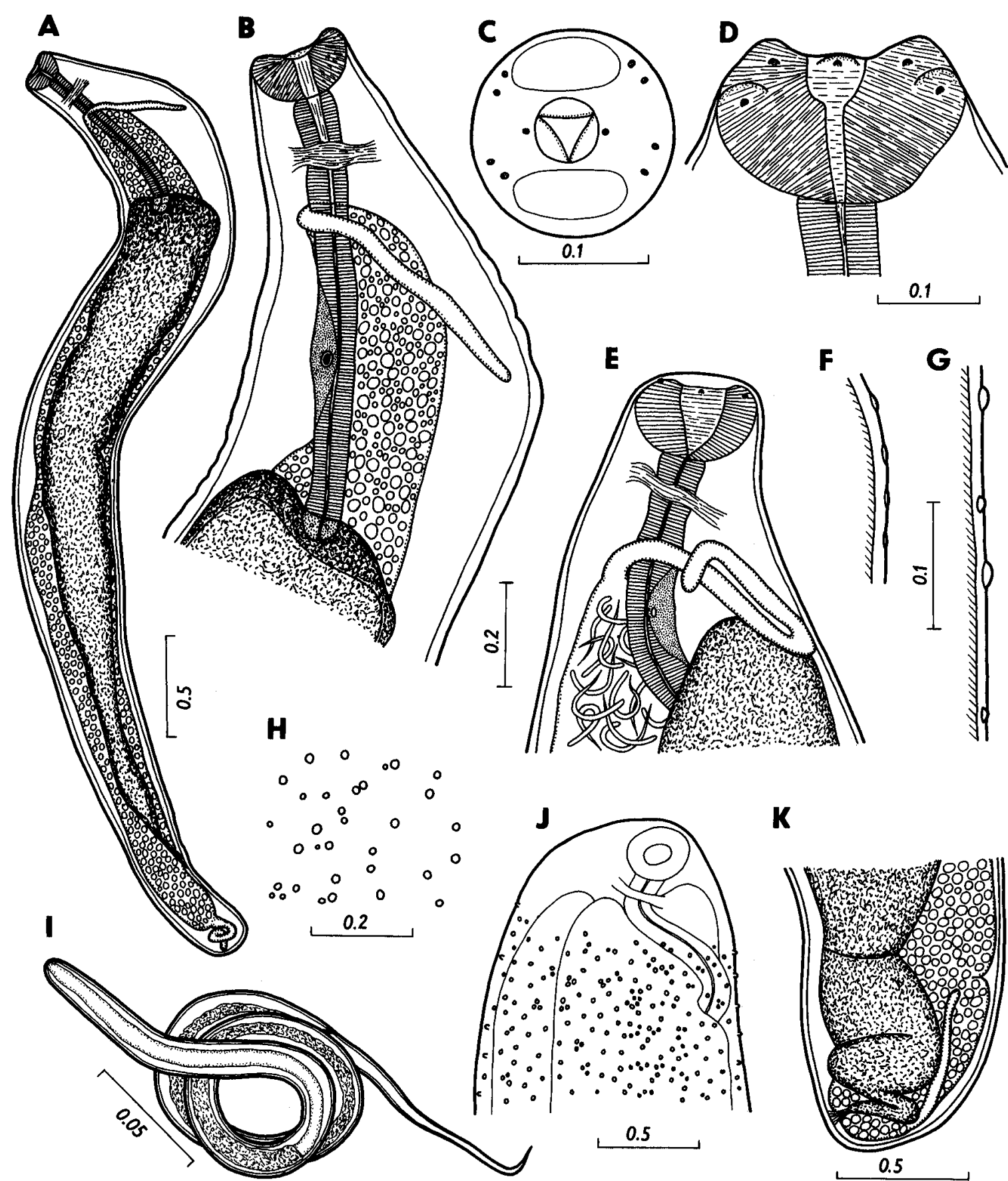

$\mathbf{K}$

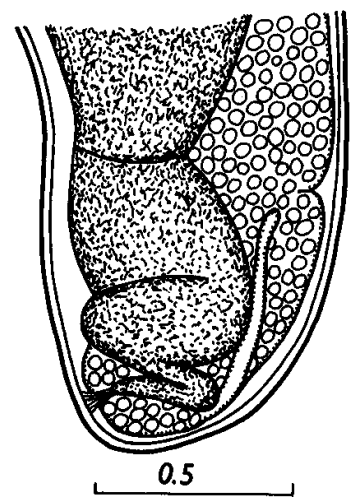

Fig. 1. Philometroides africanus sp. n., female. A - subgravid female, general view; B - anterior end of subgravid female, lateral view; C, D - cephalic end, apical and lateral views; $\mathbf{E}$ - anterior end of gravid female, lateral view; F, G - cuticular bosses of two largest specimens, lateral views; $\mathbf{H}$ - distribution of cuticular bosses on anterior part of body, apical view; I - first-stage larva from uterus; $\mathbf{J}$ - anterior end of large specimen with marked cuticular bosses; $\mathbf{K}$ - posterior end of body, lateral view. Scales in $\mathrm{mm}$.

7.766 and 9.112) densely embossed; cuticular bosses papilla-like, small, 0.006-0.012 high, being more numerous and larger at anterior part of body (embossment starts from level of nerve ring). Cuticular bosses not visible in smaller specimens. Cephalic end rounded, with anteriorly protruding dorsal and ventral lobes, these being more distinct in smaller specimens. Oral aperture large, circular, surrounded by four submedian 


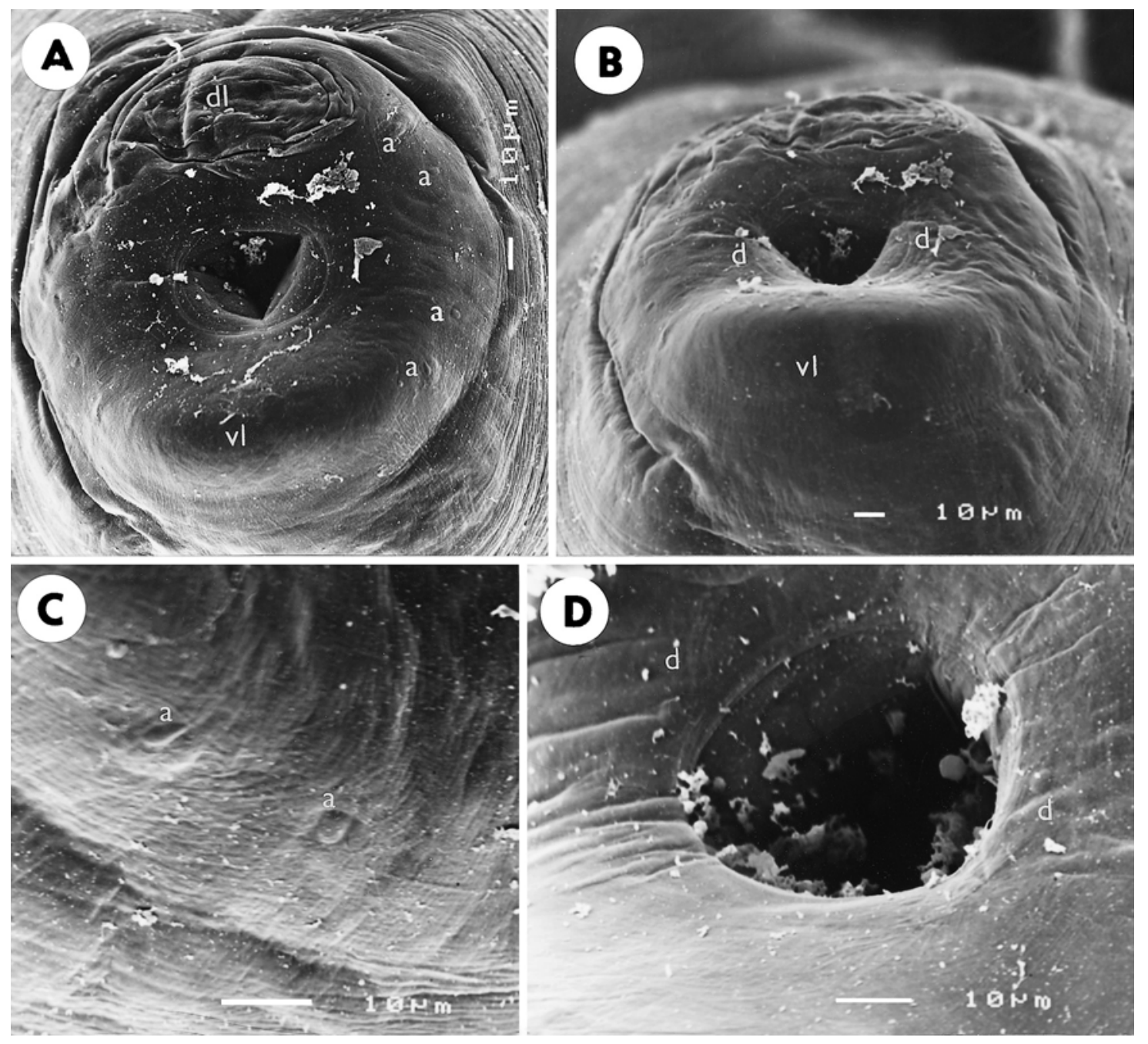

Fig. 2. Philometroides africanus sp. n., scanning electron micrographs of female cephalic end. A, B - apical and subventral views; $\mathbf{C}$ - pair of cephalic papillae; $\mathbf{D}$ - oral aperture. a - cephalic papilla; $\mathrm{d}$ - amphid; $\mathrm{dl}$ - dorsal cephalic lobe; vl - ventral cephalic lobe.

pairs of small cephalic papillae and one pair of lateral amphids; usual four single papillae in inner circle typical of some philometrids not observed. Anterior end of oesophagus forming conspicuous strongly muscular bulb, distinctly separated from cylindrical portion of oesophagus; bulb 0.136-0.313 (0.313) long and 0.2180.381 (0.381) wide. Greater posterior portion of oesophagus cylindrical, 0.109-0.177 (0.177) wide, with small poorly demarcated oesophageal gland just below its middle; cell nucleus of gland not well visible, located 0.558-1.020 (1.020) from anterior end of body. Entire oesophagus including anterior bulb 0.789-1.278 (1.197) long, representing $10-23 \%$ (13\%) of body length. Oesophagus opening into intestine through distinct valve. Nerve ring encircling anterior end of cylindrical portion of oesophagus, $0.245-0.449$ (0.449) from anterior extremity. Intestine very wide at its anterior part, often occupying 3/4 of body width; its posterior end narrow, attached by short ligament to ventral body wall at $0.394-0.680(0.394)$ from posterior end of body. Posterior end of body rounded, without any projections. Anterior ovary somewhat posterior to nerve ring level; posterior ovary near posterior extremity. Uterus occupying almost entire space of body, reaching anteriorly to level of nerve ring in largest specimens (nearly to this level in smaller ones) and posteriorly sometimes up to posterior extremity. Uterus containing large number of larvae and eggs. Larvae 0.345-0.495 (0.345) long and $0.012(0.012)$ wide, with oesophagus 0.114 in longest specimen, with tail slender and sharply pointed $(0.120$ or $24 \%$ of body length in longest specimen). 


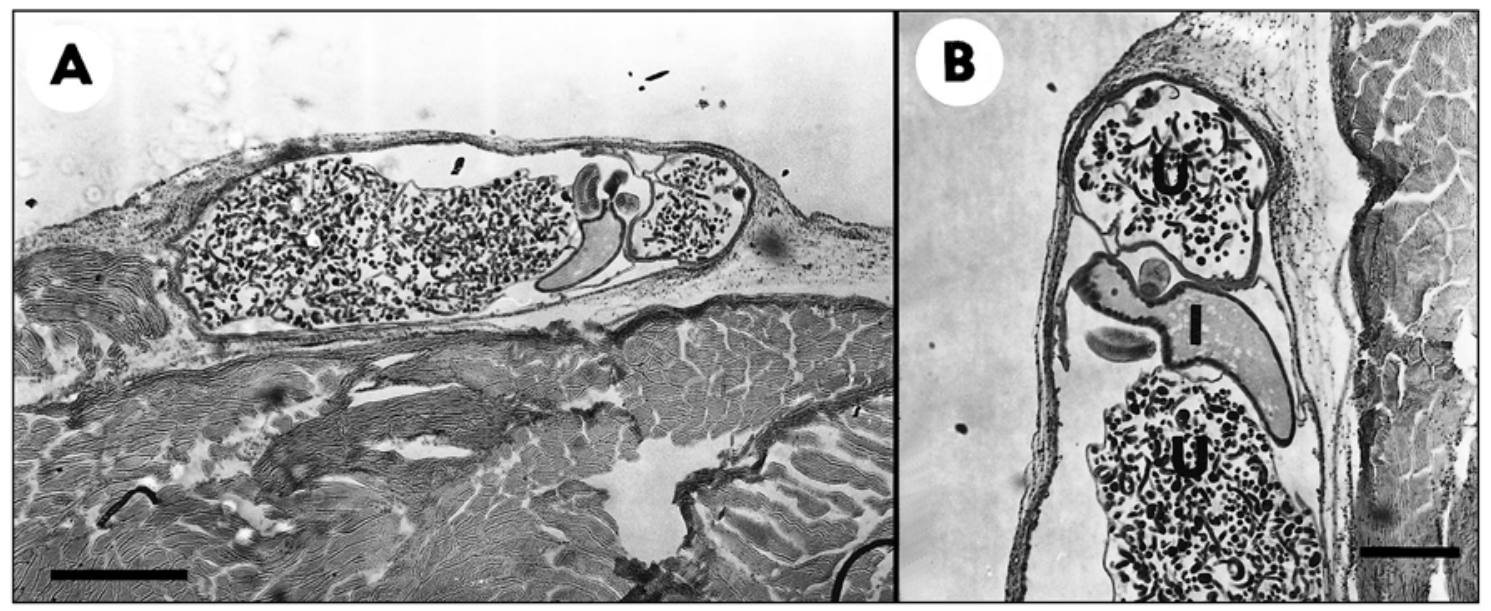

Fig. 3. Philometroides africanus sp. n., histological section through gravid female embedded in the host's skin. H\&E. A - longitudinal section through whole nodule containing coiled nematode; $\mathbf{B}$ - enlarged part of the same. I - nematode intestine; $\mathrm{U}$ - uterus filled with larvae and eggs (see cross section of oesophagus located between intestine and upper part of uterus). Scale bars: $\mathrm{A}=1 \mathrm{~mm} ; \mathrm{B}=500 \mu \mathrm{m}$.

Male: Unknown.

T y p e h o s t: African pike, Hepsetus odoe (Bloch, 1794) (Hepsetidae, Characiformes).

$\mathrm{S}$ i t e of in fection: Gill arches and inner surface of gill covers.

T y p e 1 o c a 1 i t y: Duba Lagoon in the Okavango Delta $\left(18^{\circ} 58^{\prime} \mathrm{S}, 22^{\circ} 33^{\prime} \mathrm{E}\right)$, Botswana (types collected 7 July 1999).

Prevalence and intensity: $29 \%$ (20 fish infected/ 69 examined), 1-8 (mean 4) nematodes per fish.

D e p o s i t i o n of t y p e s: Institute of Parasitology, ASCR, in České Budějovice (holotype and paratypes, Cat. No. N-764).

E t y m o lo g y: The specific name of this parasite relates to the African continent.

\section{DISCUSSION}

The present classification of philometrids, which represent a difficult group of nematode parasites, is principally based on the female morphology, because the minute males of many species and genera are unknown (Rasheed 1963, Ivashkin et al. 1971, Chabaud 1975, Moravec and Shaharom-Harrison 1989, Moravec et al. 1998). According to the present system of these nematodes, the presence or absence of cuticular bosses in females is considered a generic feature; however, Blaylock and Overstreet (1999) correctly remark that the presence of small cuticular bosses is certainly diagnostic, but can be overlooked on some species or specimens. According to the key to philometrid genera given by Moravec and Shaharom-Harrison (1989), the nematodes of the present material can be assigned to the genus Philometroides Yamaguti, 1935, even though distinct cuticular bosses are present only in larger specimens. The same was observed, for example, in the
Neotropical species Philometroides caudatus Moravec, Scholz et Vivas-Rodríguez, 1995 (Moravec et al. 1995).

Blaylock and Overstreet (1999) have recently established another monotypic philometrid genus Margolisianum Blaylock et Overstreet, 1999 (type species M. bulbosum Blaylock et Overstreet, 1999), separated from other philometrid genera mainly by the size and arrangement of cephalic papillae and characterised by the presence of minute cuticular bosses in females. However, in our opinion, the size of cephalic papillae can hardly be considered a generic feature (Moravec 1978); moreover, in most philometrids it is extremely difficult to observe cephalic papillae in females without using electron microscopy (SEM), but this method has so far been applied only for a few species. Therefore, Margolisianum is considered here a junior synonym of Philometroides and M. bulbosum is transferred to the latter as Philometroides bulbosus (Blaylock et Overstreet, 1999) comb. n. Unfortunately, at present the type species of Philometroides, $P$. seriolae (Ishii, 1931), is insufficiently known only by its females (Moravec et al. 1998) and, therefore, it may well be that subsequent studies will show a necessity to divide Philometroides into more genera, based, for example, on male morphology.

Consequently, at present there exist only two genera, Philometroides and Paraphilometroides Moravec et Shaharom-Harrison, 1989, in which species have a female with an embossed cuticle. In contrast to the new species, the monotypic genus Paraphilometroides has a more complicated structure of the cephalic end (Moravec and Shaharom-Harrison 1989); the only species of this genus, Paraphilometroides nemipteri Moravec et Shaharom-Harrison, 1989, is parasitic in the gill covers of the marine fish Nemipterus peronii (Valenciennes) in Malaysia. 
At present, the genus Philometroides comprises the following 22 species parasitic both in freshwater and marine fishes: $P$. seriolae (Ishii, 1931) (type species), $P$. sanguineus (Rudolphi, 1819), P. anguillae (Ishii, 1916), P. maplestoni (Travassos, Artigas et Pereira, 1928), $P$. nodulosus (Thomas, 1929), P. cyprini (Ishii, 1931), $P$. masu (Fujita, 1940), P. plectroplites (Johnston et Mawson, 1940), P. denticulatus Rasheed, 1965, $P$. atropi (Parukhin, 1966), P. pseudaspii Moravec et Ergens, 1970, P. dogieli Vismanis et Yukhimenko, 1974, P. oveni Parukhin, 1975, P. huronensis Uhazy, 1976, $P$. hydrocyone Fahmy, Mandour et El-Naffar, 1978, P. fulvidraconi $\mathrm{Yu}$, Wu et Wang, 1993, $P$. moraveci Vismanis et Yunchis, 1994, P. strelkovi Vismanis et Yunchis, 1994, P. caudatus Moravec, Scholz et Vivas-Rodríguez, 1995, P. pseudorasbori Wang et Yu, 1995, P. ganzhounensis Yu, 1998, and $P$. bulbosus (Blaylock et Overstreet, 1999).

In contrast to the new species, all of them, except for $P$. bulbosus, have their anterior oesophageal bulb continuous with the cylindrical portion of the oesophagus. However, P. bulbosus, a parasite of flatfishes in the USA, differs mainly in possessing markedly large cephalic papillae in the female and in having a different shape of cuticular bosses. By having a separate anterior oesophageal bulb and a markedly small oesophageal gland, the new species also resembles the monotypic genus Clavinema Yamaguti, 1935 [type and the only species: C. mariae (Layman, 1930)], differing from it distinctly in the presence of cuticular bosses and a circular (vs. triangular) oral aperture.
As compared to its congeners, $P$. africanus has an unusually small (less than $10 \mathrm{~mm}$ long vs. usually 20$600 \mathrm{~mm}$ ) gravid female equal in length to P. bulbosus only. Its larvigerous female is only slightly shorter than that of $P$. dogieli (10-28 $\mathrm{mm}$ ) and P. pseudorasbori (12$32 \mathrm{~mm}$ ); the two last named species differ from $P$. africanus mainly in having a large oesophageal gland and markedly large cephalic papillae, in addition to some other differences. Otherwise, all philometrid species can be separated from $P$. africanus by a combination of various morphological features (e.g., character of cephalic papillae, cuticular bosses and oesophageal gland, shape of cephalic end, presence or absence of caudal processes). Moreover, the location of gravid females in the host, host types and geographical distribution should also be taken into account. So far, only three East-Asian species of Philometroides, $P$. moraveci, $P$. strelkovi and $P$. pseudorasbori are known to have gravid females located under the skin of the head and in the gill covers; P. africanus is the first Philometroides species reported from Africa.

Acknowledgements. The authors thank the DEBSWANA Diamond Company, Botswana and Land Rover South Africa for financial and logistic support. Thanks are also due to the staff of the Laboratory of Electron Microscopy of the Institute of Parasitology, ASCR, in České Budějovice for their technical assistance and Mrs. Irena Husáková from the Laboratory of Helminthology of the same Institute for making histological sections and help with the preparation of illustrations. This study was partly supported by grant No. K2-022-601 from the Academy of Sciences of the Czech Republic.

\section{REFERENCES}

BLAYLOCK R.B., OVERSTREET R.M. 1999: Margolisianum bulbosum n. gen., n. sp. (Nematoda: Philometridae) from the southern flounder, Paralichthys lethostigma (Pisces: Bothidae), in Mississippi Sound, USA. J. Parasitol. 85: 306-312.

CHABAUD A.G. 1975: Keys to Genera of the Order Spirurida. Part 1. Camallanoidea, Dracunculoidea, Gnathostomatoidea, Physalopteroidea, Rictularioidea and Thelazioidea. In: R.C. Anderson, A.G. Chabaud and S. Willmott (Eds.), CIH keys to the nematode parasites of vertebrates. No. 3. Commonwealth Agricultural Bureaux, Farnham Royal, Bucks (UK), 27 pp.

IVASHKIN V.M., SOBOLEV A.A., KHROMOVA L.A. 1971: Camallanata of Animals and Man and the Diseases Caused by Them. Osnovy nematodologii 22. Nauka, Moscow, 388 pp. (In Russian.)

MERRON G.S., HOLDEN K.K., BRUTON M.N. 1990: The reproductive biology and early development of the African pike, Hepsetus odoe, in the Okavango Delta, Botswana. Environ. Biol. Fishes 28: 215-235.
MORAVEC F. 1978: Redescription of the nematode Philometra obturans (Prenant, 1886) with a key to the philometrid nematodes parasitic in European freshwater fishes. Folia Parasitol. 25: 115-124.

MORAVEC F., NAGASAWA K., OGAWA K. 1998: Observations on five species of philometrid nematodes from marine fishes in Japan. Syst. Parasitol. 40: 67-80.

MORAVEC F., SCHOLZ T., VIVAS-RODRÍGUEZ C. 1995: Philometroides caudata sp. n. (Nematoda: Philometridae) from Rhamdia guatemalensis (Pisces) in Yucatan, Mexico. Folia Parasitol. 42: 293-298.

MORAVEC F., SHAHAROM-HARRISON F. 1989: Paraphilometroides nemipteri gen. et sp. n. (Nematoda: Philometridae) from the marine fish Nemipterus peronii (Valenciennes) from Malaysia. Folia Parasitol. 36: 345350.

RASHEED S. 1963: A revision of the genus Philometra Costa, 1845. J. Helminthol. 37: 89-130. 